\title{
KRITERIA RUMAH RAMAH LINGKUNGAN (ECO-FRIENDLY HOUSE)
}

\author{
Andi Prasetiyo Wibowo 1 \\ ${ }^{1}$ Program Studi Arsitektur, Universitas Atma Jaya Yogyakarta \\ andiprasetiyo@staff.uajy.ac.id
}

\begin{abstract}
ABSTRAK
Salah satu masalah besar yang tengah dihadapi umat manusia di bumi ini adalah masalah lingkungan hidup. Perancangan bangunan ternyata juga mempunyai andil besar memicu kerusakan lingkungan dan berakibat pada turunnya kualitas hidup manusia. Rumah / hunian merupakan bangunan yang paling dekat dan paling banyak memiliki pengaruh dalam kehidupan manusia. Perlu adanya kajian dan pedoman mengenai konsep rumah ramah lingkungan (eco friendly-house) dalam rangka membantu sosialisasi mengenai konsep rumah ramah lingkungan. Dalam penulisan makalah ini metode pengumpulan data dilakukan dari pengumpulan data sekunder dengan melakukan studi kepustakaan dan studi dokumen, yaitu pengumpulan data/materi dasar. Dalam tulisan ini akan dipaparkan data-data pendukung yang dapat memberi pemahaman dan kajian mengenai konsep rumah ramah lingkungan, sehingga dapat meyakinkan pembaca dan memberikan arahan dalam proses desain rumah ramah lingkungan. Ada empat bagian yang perlu dipertimbangkan saat merancang dan membangun rumah dengan konsep ramah lingkungan, yakni ruang terbuka hijau, sistem sanitasi, efisiensi penggunaan energi / listrik serta pengolahan limbah rumah tangga (sampah), yang kesemuanya itu bisa diarahkan pada perencanaan yang memperhatikan konsep ekologis.
\end{abstract}

Kata kunci: Merancang, Mendesain, Rumah, Ramah Lingkungan

\section{PENDAHULUAN}

Salah satu masalah besar yang tengah dihadapi umat manusia di bumi ini adalah masalah lingkungan hidup. Kerusakan alam yang semakin parah, telah memicu dan memacu pemanasan global. Akibatnya bukan saja bencana alam yang terjadi bertubi-tubi, melainkan juga cuaca yang menjadi sukar diprediksi. Tidak dapat dipungkiri, bahwa manusia merupakan pihak yang paling bertanggung jawab atas kondisi alam yang memprihatinkan ini. Yang lebih mengkhawatirkan lagi, ketidakpedulian terhadap alam juga seolah-olah sudah menjadi gaya hidup hampir sebagian manusia saat ini. Namun ternyata tidak semua manusia punya sikap seperti itu, ada beberapa orang / kelompok yang sudah mulai sadar mengenai tanggung jawab terhadap lingkungan ini. Seperti halnya penelitian yang dilakukan oleh Putranto, A.D (2014) di beberapa perumahan di Kabupaten Malang, yaitu : Tambak Asri permai di Tajinan Malang, Singosari Residence, dan Mondoroko Regency, yang menilai tingkat keinginan konsumen yang memiliki RSH (Rumah Sederhana Sehat) untuk dikembangkan menjadi RSH yang berwawasan lingkungan. Hasil penelitian menunjukkan $0,6 \%$ responden menyatakan "kurang ingin"; 24,4\% menyatakan "cukup ingin" dan 75\% menyatakan "ingin". Oleh sebab itu, dengan dukungan data ini,upaya untuk mengatasi dampak pemanasan global diharapkan terus mengalami peningkatan.

Dalam perancangan bangunan, sering kali keselarasan desain dengan alam kurang diperhatikan, dalam hal pemanfaatan sumberdaya alam dan penggunaan teknologi yang tidak ramah terhadap alam. Oleh karena itu, perancangan bangunan ternyata juga mempunyai andil besar memicu pemanasan global dan berakibat pada turunnya kualitas hidup manusia. Dari semua gejala alam yang sudah terjadi, kini sudah saatnya perancangan bangunan, lebih memahami alam melalui pendekatan dan pemahaman terhadap perilaku alam lebih dalam agar tidak terjadi kerusakan alam yang lebih parah. Sasaran utama dari upaya ini adalah tidak memperparah pemanasan global, melalui upaya rancangan arsitektur yang selaras dengan alam serta memperhatikan kelangsungan ekosistem, yaitu dengan pendekatan ekologi. Frick (1998) banyak menjelaskan mengenai konsep arsitektur ekologis atau disebut juga eko-arsitektur. Eko-arsitektur tidak 
menentukan apa yang seharusnya terjadi dalam arsitektur, karena tidak ada sifat khas yang mengikat sebagai standar atau ukuran baku. Namun, eko-arsitektur mencakup keselarasan antara manusia dan lingkungan alamnya.

Pendekatan ekologi merupakan cara pemecahan masalah perancangan bangunan dengan mengutamakan keselarasan rancangan dengan alam, melalui pemecahan secara teknis dan ilmiah. Pendekatan ini diharapkan menghasilkan konsep-konsep perancangan bangunan yang ramah lingkungan, ikut menjaga kelangsungan ekosistem, menggunakan energi yang efisien, memanfaatan sumber daya alam yang tidak dapat diperbarui secara efisien, menekankan penggunaan sumber daya alam yang dapat diperbarui dengan daur ulang. Semua ini ditujukan bagi kelangsungan ekosistem, kelestarian alam dengan tidak merusak tanah, air dan udara, tanpa mengabaikan kesejahteraan dan kenyamanan manusia secara fisik, sosial dan ekonomi secara berkelanjutan. Bangunan didirikan berdasarkan rancangan yang dibuat oleh manusia yang seringkali lebih menekankan pada kebutuhan manusia tanpa memperhatikan dampaknya terhadap alam sekitarnya. Seharusnya manusia sadar betapa pentingnya kualitas alam sebagai penunjang kehidupan, maka setiap kegiatan manusia seharusnya didasarkan pada pemahaman terhadap alam termasuk pada perancangan arsitektur. Pemahaman terhadap alam pada rancangan arsitektur adalah upaya untuk menyelaraskan rancangan dengan alam, yaitu melalui memahami perilaku alam, ramah dan selaras terhadap alam. Keselarasan dengan alam merupakan upaya pengelolaan dan menjaga kualitas tanah, air dan udara dari berbagai kegiatan manusia.

Sebuah rumah yang ditumbuhi rerimbunan pohon bukan berarti sudah layak langsung disebut sebagai rumah ramah lingkungan. Kehadiran pepohonan ataupun taman di sekeliling rumah, terutama di halaman depan memang hampir selalu diidentikkan dengan rumah ramah lingkungan. Anggapan ini semakin menguat tatkala pemerintah dan berbagai pihak menggalakkan penanaman pohon di sekitar rumah dan lingkungan untuk menahan laju pemanasan global. Belum lagi adanya aturan mengenai persyaratan ruang terbuka hijau untuk hunian. Persepsi di atas kadang bisa menjadi keliru tatkala konsep rumah ramah lingkungan hanya berkutat pada penyediaan ruang terbuka hijau dan penanaman pohon saja. Belum lagi adanya pemikiran bahwa membangun rumah ramah lingkungan lebih sulit dan lebih mahal biayanya menyebabkan banyak orang menjadi keliru terhadap pemahaman rumah ramah lingkungan itu sendiri. Perlu adanya dorongan dan sosialisasi terus menerus mengenai konsep ramah lingkungan yang dapat mendatangkan keuntungan, sebagai modal untuk menggugah dan membangkitkan semangat untuk lebih mencintai lingkungan melalui pembangunan yang berwawasan lingkungan, sehingga diharapkan dapat menimbulkan keinginan dan kegairahan untuk mengadopsi konsep hunian ramah lingkungan.

Dari sekian banyak jenis bangunan, rumah / hunian merupakan bangunan yang paling dekat dan paling banyak memiliki pengaruh dalam kehidupan manusia. Dalam rangka upaya mengurangi dampak pemanasan global, dan menciptakan keharmonisan dengan alam, perlu makin digalakkan pembangunan hunian yang lebih hijau dan ramah lingkungan, yang kemudian lebih banyak dikenal sebagai konsep rumah ramah lingkungan (eco friendly-house). Perlu adanya kajian dan pedoman mengenai konsep rumah ramah lingkungan (eco friendly-house) dalam rangka membantu sosialisasi mengenai konsep rumah ramah lingkungan. 


\section{METODE PENELITIAN}

Metode penelitian merupakan ilmu yang mempelajari tentang cara penelitian ilmu tentang alatalat dalam suatu penelitian. Dalam penulisan makalah ini metode pengumpulan data dilakukan dari pengumpulan data sekunder dengan melakukan studi kepustakaan dan studi dokumen, yaitu pengumpulan data/materi dasar. Materi dasar biasanya adalah bahan tulisan, baik dari buku, buku ilmiah kamus, majalah, majalah teknik, bahan kuliah (hand-out atau catatan kuliah sendiri), ataupun dari internet (Frick,H;2008). Data tersebut mencakup pula studi kasus yang pernah ada sehingga bisa dijadikan referensi/contoh untuk mempermudah pemahaman kajian. Data yang diperoleh sudah dianalisis secara kualitatif yaitu analisis yang dilakukan dengan memahami dan merangkai data yang telah dikumpulkan dan disusun secara sistematis kemudian ditarik kesimpulan. Kesimpulan yang diambil dengan menggunakan cara berpikir deduktif yaitu cara berpikir yang mendasar kepada hal hal yang bersifat umum dan kemudian ditarik kesimpulan yang bersifat khusus.

Dalam tulisan ini akan dipaparkan data-data pendukung yang dapat memberi pemahaman dan kajian mengenai konsep rumah ramah lingkungan, sehingga dapat meyakinkan pembaca dan memberikan arahan dalam proses desain rumah ramah lingkungan.

\section{PEMBAHASAN}

\section{Ruang Terbuka Hijau}

Dalam konsep mendesain rumah ramah lingkungan, yang patut diperhatikan pada tahap awal adalah masalah desain rumah itu sendiri, bagaimana penataan ruang (denah), tata letak dan bentuk bangunan, bagaimana keselarasan dengan alam maupun lingkungan sekitar. Metode yang dapat dilakukan yaitu mengalokasikan 30-40\% dari luas lahan untuk dijadikan ruang terbuka hijau, bisa ditanami dengan rumput atau berbagai tanaman lainnya. Namun, Ruang terbuka hijau sebaiknya ditanami pepohonan yang mampu mengurangi polusi udara secara signifikan (Dwiyanto, 2009). Sifat tanaman yang menghisap karbondioksida dan mengeluarkan oksigen tentunya sangat bermanfaat untuk meningkatkan kualitas udara di lingkungan sekitar rumah. Selain itu ruang hijau berfungsi sebagai area resapan air. Kecenderungan terjadinya penurunan kualitas ruang terbuka publik di kawasan permukiman, terutama ruang terbuka hijau (RTH) pada 30 tahun terakhir dinilai sangat signifikan (Dwiyanto, 2009). Maka dengan adanya ruang hijau pada masing-masing rumah ini diharapkan dapat menyokong ketersediaan Ruang Terbuja Hijau (RTH) kawasan. Selain taman, ruang terbuka hijau dapat pula berbentuk koridor hijau jalan dan koridor hijau sungai (Purwanto, E. ,2007).
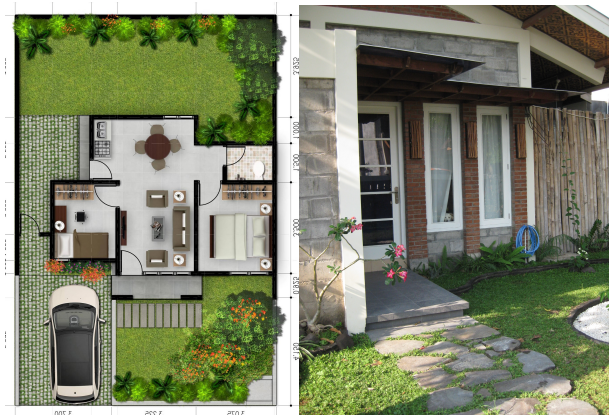

Gambar 1. Contoh rumah dengan ruang terbuka hijau 


\section{Green Roof}

Dengan makin terbatasnya lahan untuk hunian, pengadaan ruang terbuka hijau menjadi semakin sulit dilakukan. Ada alternatif lain dalam penyediaan ruang terbuka hijau tanpa harus mengorbankan lahan. Pembuatan taman di atas atap bangunan atau biasa disebut green roof / roof garden bisa dijadikan solusi keterbatasan lahan yang dimiliki. Green roof selain bisa difungsikan sebagai taman juga membantu menurunkan suhu panas di dalam rumah. Bila pemanfaatan green roof diimplementasikan secara luas, bukan tidak mungkin dapat meningkatkan kualitas lingkungan di kota dan secara tidak langsung mengatasi fenomena Urban Heat Island (UHI). (APSARI, J. ; 2007)

Konstruksi dari "green roof" secara singkat dijelaskan sebagai berikut (mulai dari lapisan terbawah). Water Proof Membrane ; lapisan untuk menutupi keseluruhan permukaan atap. Melindungi atap dari efek kebocoran. Drain Mat; lapisan sebagai tempat/ruang bergeraknya aliran air, baik dari penyiraman maupun air hujan. Filter Cloth ; lapisan untuk memisahkan lapisan drain mat dengan media pertumbuhan. Growing Medium ; lapisan tempat pertumbuhan tanaman.

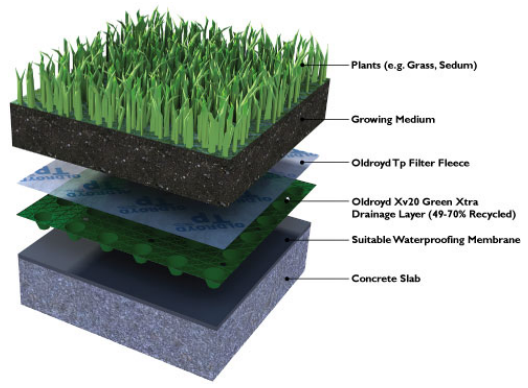

Gambar 1. Konstruksi /lapisan roof garden.

(sumber: http://www.rudydewanto.com/2011/01/green-roof-di-hutan-beton.html)

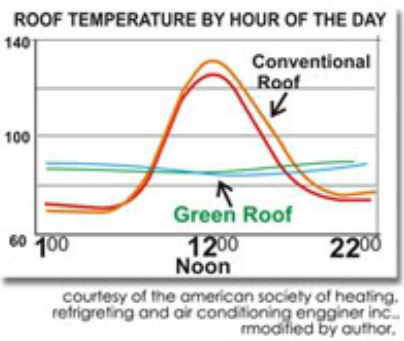

Gambar 2. Roof garden dapat menurunkan suhu pada atap bangunan

(sumber : http://usatoday30.usatoday.com/tech/columnist/aprilholladay/2006-04-24-greenroofs_x.htm)

\section{Green Wall}

Selain green roof, dinding bangunan atau dinding pagar dapat pula ditumbuhi tanaman rambat sebagai "kulit" bangunan (green wall) yang berfungsi sebagai penghambat radiasi panas matahari dan menyerap polutan sekaligus penghasil oksigen, serta dapat menyejukkan lingkungan sekitar secara visual. Pengolahan tanaman pada fasad dapat berupa penempelan jenis tanaman pada dinding, desain tirai tanaman gantung hingga desain knock-down (menggantungkan pot-pot tanaman seperti tanaman anggrek atau sejenisnya). (Prianto, E. ; 2012). Dalam penelitian lainnya, Prianto (2013) menampilkan data bahwa pada rumah yang yang menggunakan green wall, suhu udara dalam ruangannya lebih cepat dan lebih lama durasi 
dinginnya yaitu selama 11 jam dari total 13 jam waktu efektif pencahayaan matahari pagi hingga petang $(85 \%)$, dibandingkan dengan ruangan yang tidak menggunakan green wall yaitu sebesar 8 / 13 jam (62\%). Sedangkan perbedaan suhu udara eksetrior dan interior pada kondisi bangunan dengan green wall bisa mencapai $2^{\circ} \mathrm{C}$, sedangkan pada kondisi bangunann yang tidak menggunakan green wall tidak lebih dari $1^{\circ} \mathrm{C}$.
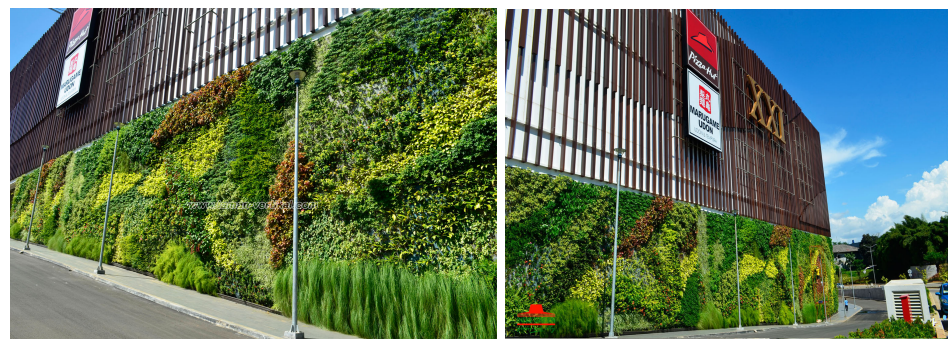

Gambar 3. Tanaman rambat sebagai green wall.

(sumber : http://www.taman-vertikal.com/vertical-garden)

\section{Penggunaan Material Bangunan yang Menunjang Konsep Ramah Lingkungan.}

Pada saat membangun rumah, gunakan material / bahan bangunan dengan memanfaatkan perkembangan teknologi bahan bangunan untuk mendukung terciptanya hunian / rumah yang ramah lingkungan. Sebagai contoh, pertimbangan pemilihan rangka atap yang menggunakan material baja ringan daripada penggunaan kayu, dengan demikian konsumsi kayu untuk kebutuhan rangka atap dapat dikurangi. Tidak bisa dibayangkan apabila saat ini seluruh kebutuhan bahan bangunan perumahan menggunakan material kayu sebagai bahan utamanya. Padahal kayu tidak hanya dimanfaatkan untuk bahan bangunan saja. Penebangan hutan secara liar dan tidak terkontrol serta tidak diimbangi dengan upaya perbaikan pasca-penebangan menyebabkan kerusakan lingkungan. Penggunaan baja ringan dinilai agak sedikit lebih mahal dibanding dengan menggunakan konstruksi kayu, namun hal tersebut sepadan dengan adanya berbagai keuntungan yang didapat dan juga untuk mendukung program ramah lingkungan. Namun dengan berkembang pesatnya teknologi dan industri rangka atap baja ringan tersebut, pemilihan jenis dan produk rangka atap baja ringan memerlukan pertimbangan tersendiri. Pertimbangan yang dapat digunakan antara lain: kualitas material/bahan, pelayanan purna jual, kecepatan pengerjaan, dan faktor harga.

Pemilihan material untuk penerapan bagian interior dapat pula mendukung terciptanya kondisi yang nyaman dan mendukung konsep rumah ramah lingkungan khususnya dalam hal menghemat energi penggunaan pendingin udara (AC). Penelitian yang dilakukan oleh Dianita, R., \& Sutrisno, S. (2014) yang menyebutkan bahwa penggunaan material marmer dan gipsum keduanya sama-sama dapat menurunkan suhu di dalam ruangan sehingga di dalam ruangan terasa sejuk dan dingin.

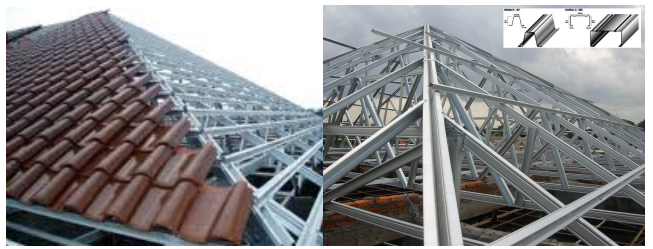

Gambar 4. Rangka atap baja ringan. Mendukung proses konsep ramah lingkungan, karena dapat mengurangi kebutuhan kayu untuk konstruksi. 


\section{Maksimalkan Penghawaan dan Pencahayaan Alami.}

Rumah ramah lingkungan hendaknya banyak memiliki bukaan untuk sirkulasi udara, agar selalu mendapatkan pasokan udara bersih. Rumah dengan desain seperti ini memberikan dua keuntungan, yakni meningkatkan kualitas kesehatan penghuni dan hemat energi.

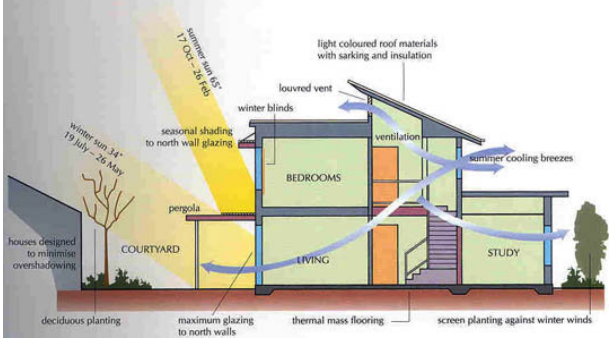

Gambar 5. Konsep rumah yang memaksimalkan penghawaan dan pencahayaan alami

Selain itu, rumah dengan konsep ini banyak memanfaatkan sinar matahari untuk pencahayaan. Prinsipnya memaksimalkan terangnya dan mengurangi teriknya. Karena itu sedapat mungkin setiap bagian dari rumah mendapatkan paparan sinar matahari yang cukup. Sementara untuk mengurangi sengatan matahari bisa disiasati dengan membuat kanopi pada tiap jendela. Suhu ruangan dapat meningkat seiring dengan banyaknya sinar matahari langsung yang masuk. Oleh sebab itu jumlah dan lamanya sinar matahari yang masuk ke dalam ruangan perlu dibatasi, khususnya sinar matahari langsung. Bangunan sebisa mungkin hanya menerima cahaya dari kubah langit atau cahaya matahari tidak langsung (Mediastika,2013). Hal ini dapat mengurangi panas yang dibawa oleh sinar matahari namun tetap mendapatkan cahaya sebagi penerangan alami.

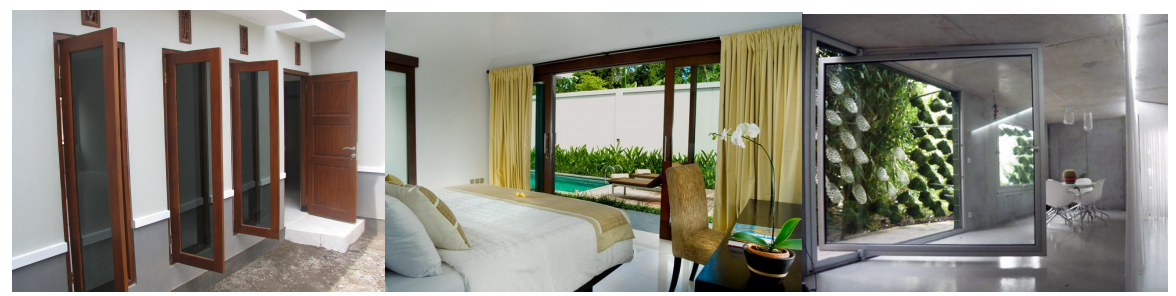

Gambar 6. Bukaan (jendela) yang besar memaksimalkan udara dan cahaya ke dalam ruang.

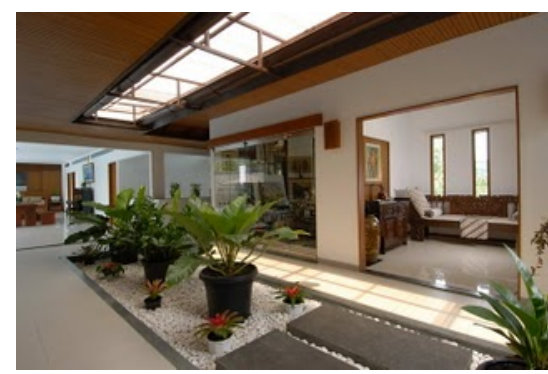

Gambar 7. Skylight /void sebagai alternatif bukaan pada bagian atap bangunan, untuk memasukkan sinar matahari ke dalam bangunan.

\section{Efisiensi Penggunaan Energi / Listrik}

Listrik adalah salah satu kebutuhan vital pada setiap rumah berpenghuni. Gunakan listrik dengan bijak, pilih alat-alat listrik yang mempunyai daya watt rendah. Ganti lampu pijar dengan lampu hemat energi. Sistim penghawaan dan pencahayaan buatan merupakan sumber pemborosan 
energi terbesar dalam bangunan, yaitu sekitar $60 \%$ dari energi yang digunakan dalam bangunan. (Hanum, M., \& Murod, C.). Pemborosan energi dari sisi penghawaan dan pencahayaan dapat dikurangi apabila bangunan didesain secara tepat.

Jika memungkinkan, gunakan sumber energi listrik alternatif selain dari PLN. Ada banyak jenis sumber listrik alternatif, kincir angin, mikro hidro, tenaga surya dan sebagainya. Namun dari beberapa energi alternatif tersebut, sepertinya listrik tenaga surya lebih cepat dan mudah diadaptasi untuk digunakan / diterapkan penggunaannya. Hal ini dibuktikan dengan mulai banyaknya penerangan jalan maupun lampu pengatur lalu lintas yang menggunakan listrik tenaga surya. Walau saat ini teknologi tenaga surya yang menggunakan solar panel masih dirasa cukup mahal untuk sebuah rumah tinggal, namun siapa tahu beberapa tahun mendatang sistem listrik tenaga surya akan jauh lebih murah, tak ada salahnya jika sejak sekarang hal itu menjadi cita-cita bersama.

Efisiensi penggunaan listrik dalam rangka menciptakan lingkungan yang berkelanjutan jangan hanya dilihat sebagai penerapan teknologi dan banguan modern. Kategori bangunan ramah lingkungan dan menerapkan efisiensi penggunaan listrik juga dapat disematkan pada bangunanbangunan tradisional, seperti halnya hasil penelitian Wahyudi, A. (2013) terhadap kampung tradisional di Jawa Barat, yaitu Kampung Bojong Koneng yang ada di Sentul, Bogor dengan Kampung Kranggan yang ada di Pondok Gede, Bekasi.

\section{Sistem Sanitasi}

Sistem sanitasi terkait dengan pemanfaatan air bersih dan pengolahan air kotor / limbah yang di akibatkan dari aktivitas rumah tangga. Rumah yang ideal mempunyai sistem saluran air bersih, air kotor, dan air limbah (tinja) yang dibuat terpisah dan memenuhi persyaratan teknis agar dapat berfungsi dengan baik. Penggunaan sumber air bersih dari air tanah dengan bantuan pompa dialirkan ke bak penampung air terlebih dahulu, kemudian dialirkan ke saluran air bersih dengan sistem gravitasi. Dengan adanya penampung air, akan menghemat listrik akibat penggunaan pompa listrik.

Air merupakan sumber kehidupan yang dibutuhkan dalam kehidupan sehari-hari, termasuk untuk keperluan rumah tangga. Namun, penggunaan air yang kurang bertanggungjawab seringkali terjadi pada daerah yang tidak mengalami kesulitan dalam penyediaan sumber air bersih. Padahal salah satu dampak dari pemanasan global adalah menipisnya persediaan air. Hal ini bisa terjadi karena ulah manusia yang kurang arif dalam merawat daerah-daerah resapan air. Manusia harusnya bersikap prihatin dengan tidak boros dalam menggunakan air. Penggunaan bak mandi sebaiknya sudah mulai ditinggalkan dan diganti dengan penggunaan shower, karena kamar mandi yang masih menggunakan sistem bak mandi lebih memboroskan pemakaian air.

Ketersediaan air tanah perlu dilakukan mengingat sebagian besar sumber air bersih mengandalkan air tanah. Beberapa hal yang dapat dilakukan antara lain : Air bekas mandi, mencuci sayuran, mencuci piring, mencuci pakaian, ditampung, disaring (dinetralisasi), dan diresapkan secara alami ke dalam sumur resapan air yang dilengkapi filter alami (pasir, kerikil, ijuk, pecahan bata/genting). Jika memungkinkan, air hujan dapat pula ditampung, diserap, dan dialirkan ke dalam pipa serta diresapkan ke dalam sumur resapan air. Hampir tidak ada buangan percuma dari konsep rumah ramah lingkungan, semuanya dimanfaatkan sesuai dengan konsep daur ulang. Rumah ramah lingkungan menyerap air yang jatuh sebanyak-banyaknya ke dalam tanah (zero run off). 

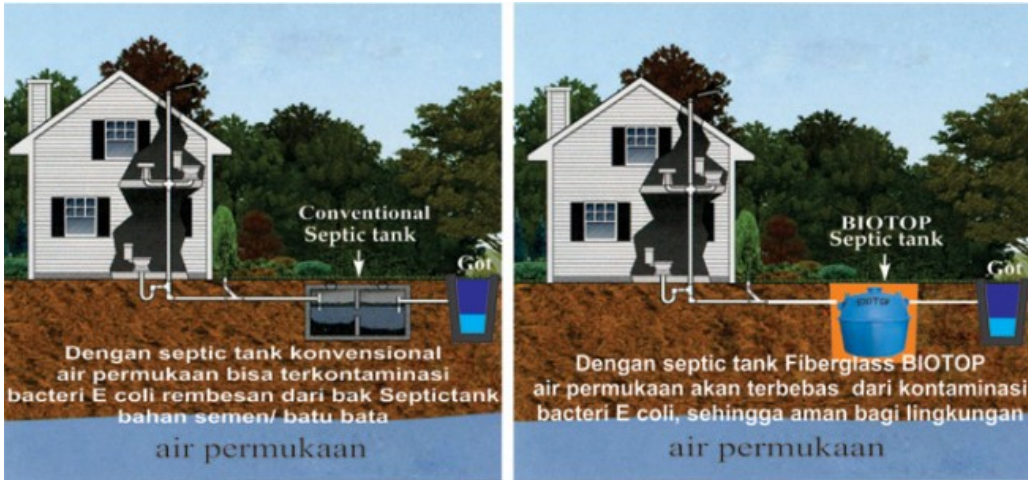

Gambar 8. Teknologi septic tank fabrikasi.

(sumber : http://www.biotopseptictank.com/produk/septic-tank-biotop/)

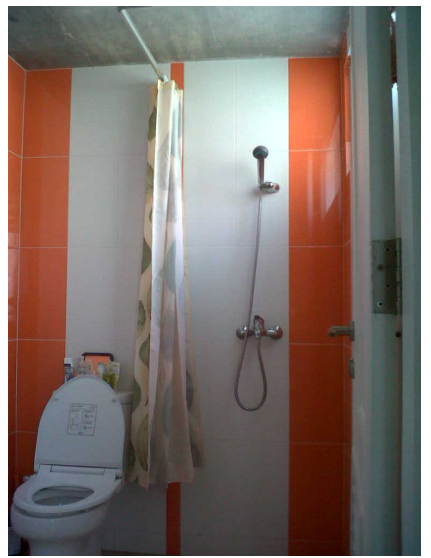

Gambar 9. Shower. Selain menghemat penggunaan air, kamar mandi yang menggunakan shower tidak harus membutuhkan ruang yang luas.
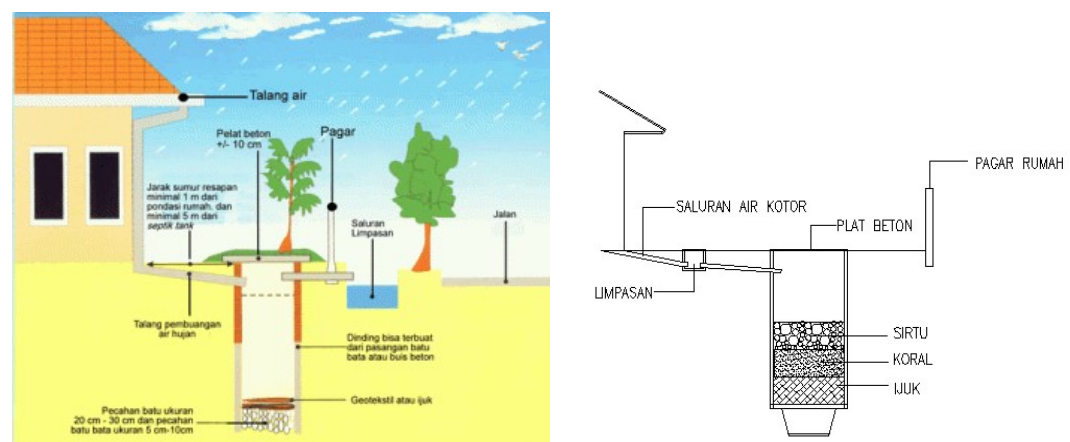

Gambar 10. Sumur Resapan untuk menampung limpasan air hujan dari atap rumah. (Sumber : http://resapanair.blogspot.co.id/)

\section{Pengolahan Limbah Rumah Tangga (Sampah)}

Sampah menjadi bagian penting penting khususnya bagi permukiman di kota yang padat penduduknya. Proses pengangkutan dan pengolahan sampah perlu dipikirkan bersama agar tidak terjadi permasalahan di kemudian hari. Banyak kejadian dan kasus pengolahan sampah yang sudah terjadi, seperti kasus dialami Pemprov DKI Jakarta beberapa waktu lalu terkait dengan Tempat Pembuangan Akhir (TPA) di Bantargebang, Bekasi. Hampir sama dengan kasus di atas, 
kota Bandung juga pernah mendapat julukan baru sebagai kota sampah, akibat dari tidak tertanganinya sampah di kota tersebut. Penanganan sampah tidak hanya permasalahan pemerintah, namun juga masalah kita semua sebagai warga masyarakat.

Rumah merupakan titik awal dalam rangkaian pengelolaan sampah. Dimulai dengan melakukan pemilahan sampah organik dan anorganik. Langkah sederhana ini selain mengurangi volume sampah juga mempermudah dalam proses memilah sampah jika akan dimanfaatkan kembali. Sisa-sisa sampah organik seperti sayuran, buah-buahan, dan makanan diolah kembali menjadi pupuk tanaman, baik yang berbentuk cair maupun padat. Salah satu cara untuk mengolah sampah organik adalah dengan memanfaatkan lubang biopori di sekitar halaman rumah. Masukan sisa-sisa sampah organik ke dalam lubang biopori. Beberapa hari kemudian Anda bisa mengambilnya untuk dijadikan pupuk organik.

Berikut dijelaskan proses membuat lubang biopori : pertama, membuat lubang silindris ditanah dengan diameter 10-15 cm dan kedalaman sekitar 80-100 cm, tetapi jangan melebihi muka air tanah. Lubang tersebut dapat dibuat dengan bambu, pipa besi atau bor tanah dengan jarak antar lubang 50-100 cm. Kemudian lubang diisi dengan sampah organik. Fauna tanah (seperti cacing) datang dengan sendirinya dan masuk ke dalam lubang untuk mencari perlindungan dan bahan makanan. Fauna tanah tersebut berkembang biak menciptakan biopori (liang) yang dapat mempercepat laju peresapan air dalam lubang, serta mempercepat proses perombakan sampah organik menjadi kompos dan tidak menimbulkan bau. Setiap 5 hari sekali dilakukan penambahan sampah organik. Kompos yang terbentuk dalam lubang resapan biopori dapat diambil untuk menyuburkan tanaman. Mulut atau pangkal lubang dikelilingi adukan semen selebar 2-3 cm setebal $2 \mathrm{~cm}$ supaya tanah tidak jatuh ke lubang (longsor). Dapat pula diberi tutup berupa kawat anyam besi pada mulut lubang. Jumlah lubang resapan biopori ditentukan berdasarkan luas lahan, yaitu setiap 50 meter persegi luas lahan dibuat 10 lubang.

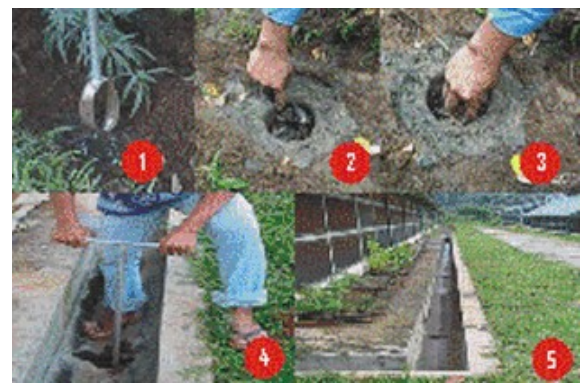

Gambar 11.Proses Pembuatan Lubang Biopori

(sumber : http://sumurresapan.blogspot.co.id/2008/10/lubang-resapan-biopori.html)

\section{KESIMPULAN}

Dari beberapa hal dalam pembahasan di atas, pada saat membuat hunian dengan konsep ramah lingkungan (eco-friendly house) terdapat 4 (empat) pengelompokan/bagian yang perlu diperhatikan, yakni ruang terbuka hijau baik itu melalui area terbuka tidak terbangun, maupun dengan pemanfaatan teknologi seperti green roof dan green wall, sistem sanitasi yang mendukung penghematan dan ketersediaan air bersih, efisiensi penggunaan energi (termasuk listrik) melalui pemanfaatan teknologi bahan bangunan, serta pengolahan limbah rumah tangga (sampah) yang dapat memberi nilai tambah bagi penghuninya. Semua hal di atas diarahkan pada perencanaan yang memperhatikan konsep ekologis dan dapat dijadikan pedoman dalam merencanakan dan membangun rumah yang ramah lingkungan. 
Menciptakan lingkungan hunian yang nyaman perlu dimulai dengan tindakan nyata dan dapat dilakukan dengan hal-hal kecil terlebih dahulu kemudian menjadikan hal itu sebagai kebiasaan, misalnya merawat tanaman, hemat dalam penggunaan air dan listrik, memilah-milah sampah, dan lain sebagainya. Optimisme dalam menciptakan masa depan bumi yang lebih sehat dan nyaman dapat terasa jika seluruh elemen masyarakat menyadari pentingnya hidup yang selaras dengan alam.

\section{REFERENSI}

APSARI, J. (2007). Kajian Pengembangan Roof Garden Di Metropolitan Dalam Upaya Mengatasi Fenomena Urban Heat Island. Skripsi. Intitut Pertanian Bogor

Dianita, R., \& Sutrisno, S. (2014). Analisa pemilihan material bangunan dalam mewujudkan green building (studi kasus: gedung kantor perwakilan bank Indonesia Solo). Pendidikan Teknik Bangunan, 4(4).

Dwiyanto, A. (2009). Kuantitas dan kualitas ruang terbuka hijau di permukiman perkotaan. Teknik, 30(2), 88-92.

Frick, H., \& Suskiyatno, F. B. (1998). Dasar-dasar eko-arsitektur: konsep arsitektur berwawasan lingkungan serta kualitas konstruksi dan bahan bangunan untuk rumah sehat dan dampaknya atas kesehatan manusia. Penerbit Kanisius. Yogyakarta

Frick, H. (2008). Pedoman Karya Ilmiah. Penerbit Kanisius. Yogyakarta

Hanum, M., \& Murod, C. (2011). EFISIENSI ENERGI PADA 'SMART BUILDING' UNTUK ARSITEKTUR MASA DEPAN. Prosiding Seminar Nasional AVoER ke-3. Palembang, 26-27 Oktober 2011. ISBN : 979-587-395-4

Mediastika, C. E. (2013). Hemat Energi dan Lestari Lingkungan Melalui Bangunan. Penerbit ANDI. Yogyakarta, p.161.

Prianto, E. (2012). Strategi disain fasad rumah tinggal hemat energi. Jurnal Pembangunan Kota Semarang RIPTEK, 6(1), 55-65.

Prianto, E. (2013). Aplikasi Green Wall pada Gedung Pemerintah dalam Menciptakan Kenyamanan di Kota Semarang: Sebuah Studi Awal. Jurnal Pembangunan Kota Semarang Riptek, 1-16.

Purwanto, E. (2007). Ruang terbuka Hijau di Perumahan Graha Estetika Semarang. ENCLOSURE, 6(1), 49-58.

Putranto, A. D. (2014). Pengembangan Rumah Sederhana Sehat (RSH) Menjadi Rumah Sederhana Sehat Berwawasan Lingkungan Di Kabupaten Malang. Jurnal Ruas, 11(2), 6074.

Wahyudi, A. (2013). Perancangan Bangunan Tradisional Sunda sebagai Pendekatan Kearifan Lokal, Ramah Lingkungan dan Hemat Energi. Prosiding PESAT, 5. 